medRxiv preprint doi: https://doi.org/10.1101/2020.09.25.20201939; this version posted October 15, 2020. The copyright holder for this preprint (which was not certified by peer review) is the author/funder, who has granted medRxiv a license to display the preprint in It is made available under a CC-BY-ND 4.0 International license .

\title{
Inferred resolution through herd immmunity of first COVID-19 wave in Manaus, Brazilian Amazon
}

Thomas A. A. Prowse, ${ }^{1, \mathbb{I}}$, T. Purcell ${ }^{2, \mathbb{,}}$, Djane C. Baía-da-Silva ${ }^{3}$, V. Sampaio ${ }^{4}$, Wuelton M. Monteiro ${ }^{5}$, James Wood ${ }^{6}$, I. Mueller ${ }^{7,8}$, Jodie McVernon ${ }^{9,10,11}$, Marcus V. G.

$$
\text { Lacerda }^{12, \#} \text {, Joshua V. Ross }{ }^{1, \#}
$$

${ }^{1}$ School of Mathematical Sciences, The University of Adelaide, Adelaide, South Australia 5005, Australia

${ }^{2}$ Victorian Infectious Diseases Reference Laboratory Epidemiology Unit at The Peter Doherty Institute for Infection and Immunity, The University of Melbourne and Royal Melbourne Hospital, Melbourne, Victoria 3000, Australia

${ }^{3}$ Fundação de Medicina Tropical Dr Heitor Vieira Dourado, Manaus, Brazil

${ }^{4}$ Fundação de Vigilância em Saúde; Fundação de Medicina Tropical Dr Heitor Vieira Dourado, Manaus, Brazil

${ }^{5}$ Universidade do Estado do Amazonas; Fundação de Medicina Tropical Dr Heitor Vieira Dourado, Manaus, Brazil

${ }^{6}$ School of Population Health, UNSW Sydney, Australia

${ }^{7}$ Population Health and Immunity Division, Walter + Eliza Hall Institute, Parkville, Victoria, Australia

${ }^{8}$ Department of Medical Biology, FMDHS, University of Melbourne, Parkville; Department of Parasites and Insect Vectors, Institut Pasteur, Paris, France

${ }^{9}$ Victorian Infectious Diseases Reference Laboratory Epidemiology Unit at The Peter Doherty Institute for Infection and Immunity, The University of Melbourne and Royal Melbourne Hospital, Melbourne, Victoria 3000, Australia

${ }^{10}$ Centre for Epidemiology and Biostatistics, Melbourne School of Population and Global Health, The University of Melbourne

${ }^{11}$ Infection and Immunity Theme, Murdoch Childrens Research Institute, Parkville.

${ }^{12}$ Instituto Leônidas \& Maria Deane, Fiocruz; Fundação de Medicina Tropical Dr Heitor Vieira Dourado, Manaus, Brazil

\#Joshua V. Ross, School of Mathematical Sciences, The University of Adelaide, Adelaide, South Australia 5005, Australia

II equal first authors

\# Noqual.last authors

NOTE: This preprint reports new research that has not been certified by peer review and should not be used to guide clinical practice. 
medRxiv preprint doi: https://doi.org/10.1101/2020.09.25.20201939; this version posted October 15, 2020. The copyright holder for this preprint (which was not certified by peer review) is the author/funder, who has granted medRxiv a license to display the preprint in It is made available under a CC-BY-ND 4.0 International license .

\section{Abstract}

\section{Background}

3 As in many other settings, peak excess mortality preceded the officially reported 'first wave' 4 peak of the COVID-19 epidemic in Manaus, Brazil, reflecting delayed case recognition and 5 limited initial access to diagnostic testing.

\section{$6 \quad$ Methods and Findings}

7 To avoid early information bias, we used detailed age and gender stratified death certificate 8 and hospitalisation data to evaluate the epidemic's trajectory and infer the cause of its decline

9 using a stochastic model. Our results are consistent with heterogenous transmission reducing 10 from mid-April 2020 due to the development of herd immunity. Relative to a baseline model 11 that assumed homogenous mixing across Manaus, a model that permitted a self-isolated 12 population fraction reduced the population-wide attack rate required to drop the effective 13 reproduction number below one from $62 \%$ to $47 \%$, and reduced the final attack rate from $86 \%$ 14 to $65 \%$. In the latter scenario, a substantial proportion of vulnerable, older individuals remained susceptible to infection.

\section{Conclusions}

17 Our models indicate that the development of herd immunity amongst the mixing proportion of 18 the Manaus population had effectively halted the COVID-19 epidemic by late July 2020. Given uncertainties regarding the distancing behaviours of population subgroups with different social and economic characteristics, and the duration of sterilising or transmission-modifying

21 immunity in exposed individuals, we conclude that the potential for epidemic outbreaks 
medRxiv preprint doi: https://doi.org/10.1101/2020.09.25.20201939; this version posted October 15, 2020. The copyright holder for this preprint (which was not certified by peer review) is the author/funder, who has granted medRxiv a license to display the preprint in It is made available under a CC-BY-ND 4.0 International license.

22 remains, but that future waves of infection are likely to be much less pronounced than that 23 already experienced. 
medRxiv preprint doi: https://doi.org/10.1101/2020.09.25.20201939; this version posted October 15, 2020. The copyright holder for this preprint (which was not certified by peer review) is the author/funder, who has granted medRxiv a license to display the preprint in It is made available under a CC-BY-ND 4.0 International license.

\section{Introduction}

25 Globally, marked differences have been observed in morbidity and mortality due to SARS-

CoV-2 infection. This variability mostly reflects the extent and timeliness of spontaneous and

27 imposed changes in social mixing and the sensitivity of surveillance systems to detect cases and deaths [1]. Many countries that successfully constrained the initial epidemic through distancing measures are now experiencing second waves in still-susceptible populations [2].

30 Estimates of $R_{0}$ for SARS-CoV-2 in the range 2 to $6[3,4]$ suggest that population immunity

31 of approximately $50-80 \%$ is required to achieve herd protection. However, heterogeneous behaviour, infectivity and immunity within subpopulations could plausibly decrease this threshold to $10-20 \%$ [5]. Controversy remains regarding the extent of population exposure required to achieve such constraint [6].

Comparison of population attack rates to inform this question is made challenging by imperfect case ascertainment, compounded by limited diagnostics and overwhelmed health systems, particularly in high incidence settings. Assessment of epidemic activity therefore requires the use of less biased metrics than confirmed case reports. Excess mortality is an objective measure which, with cause-of-death certification, can be used as an indicator of direct and indirect COVID-19 associated mortality [7]. With hospitalisations data, it can

41 inform retrospective estimation of cumulative cases and deaths [8].

Brazil experienced a severe first wave of COVID-19 disease, with mass mortality reported in many states, mainly in the north where seasonality of respiratory infections contributed to higher vulnerability. A socialized health system provided free and global access to tertiary care hospitals, but inequalities might explain different mortality rates in the population [9]. In Manaus, the highly urbanised capital of Amazonas state, the first case of COVID-19 was 
medRxiv preprint doi: https://doi.org/10.1101/2020.09.25.20201939; this version posted October 15, 2020. The copyright holder for this preprint (which was not certified by peer review) is the author/funder, who has granted medRxiv a license to display the preprint in It is made available under a CC-BY-ND 4.0 International license .

reported on 13 March 2020 [10]. By 11 August 2020, 37,597 cases and 2,051 deaths were reported [11].

However, burial and death records indicate far higher mortality than official reports, suggesting

50 late recognition of importation and underreporting. Previous studies have assumed that the first wave in Manaus was significantly mitigated by non-pharmaceutical interventions (NPIs) [12].

While these restrictions may have partly constrained early transmission, local reports indicate that implementation was highly variable [13]. Moreover, a possible role for immunity is suggested by the observation of declining cases and deaths over a period in which restrictions were officially eased.

We use death certificate and hospitalisation records to parameterise an epidemiological model of the COVID-19 epidemic in Manaus. The model allows inference of age- and genderstratified infection-fatality ratios to explore evidence for development of herd immunity as a driver of local epidemic resolution, with implications for the ongoing risk posed by SARS-

$60 \mathrm{CoV}-2$ to this population.

\section{Methods}

\section{Excess mortality and reported causes}

63 Death certificate data from January 2015 to July 2020 were sourced from the Brazilian

64 Ministry of Health Mortality Information System (SIM). Information on age, gender, and 65 cause and date-of-death was recorded. Cause of death was reported using the World Health 66 Organization's (WHO) International Classification of Diseases $10^{\text {th }}$ revision (ICD-10). The 672010 population census and the 2019 municipal population estimates were accessed from the 68 Brazilian Institute of Geography and Statistics (IBGE). This project was approved by the 
medRxiv preprint doi: https://doi.org/10.1101/2020.09.25.20201939; this version posted October 15, 2020. The copyright holder for this preprint (which was not certified by peer review) is the author/funder, who has granted medRxiv a license to display the preprint in It is made available under a CC-BY-ND 4.0 International license . 4.033.218).

Background mortality was calculated by averaging the number of deaths observed per week, commencing on January 1 each year, for the previous 5 years (2015-2019). Background mortality was further stratified by gender and into 5-year age bands, culminating at $75+$. For each subgroup, we subtracted this five-year average from deaths observed for the period between March 19 and June 24 of 2020 to determine excess deaths. This period was selected as excess mortality was first observed in the week beginning on March 19 and the data returned to baseline background mortality in the week beginning on June 25 .

The age and gender structure reported in the 2010 population census was used to estimate the 2019 population size for each age and gender class. Population estimates were aggregated into 5-year age bands. The 5-year population estimates for 2019 were used to determine excess mortality, as a proportion of the population.

The ICD-10 codes assigned to each death certificate were aggregated into 7 categories: diseases of the respiratory system (J00-J99), circulatory system (I00-I99), endocrine system (E00-E99), unattended (R98) and unknown cause of death (R99), coronavirus infection (B34.2) and all remaining codes were categorised as 'other'. All analyses were performed using R software.

\section{Hospitalisation data}

87 Hospitalisation data for patients admitted to all hospitals (private and public) in Manaus from January 2020 to July 2020 was accessed from the Influenza Surveillance Information System

89 (SIVEP-Gripe). Data entry in this system is compulsory by law. A deidentified line list

90 included patient demographics, comorbidities, clinical symptoms, investigations, clinical management and outcome data. 
medRxiv preprint doi: https://doi.org/10.1101/2020.09.25.20201939; this version posted October 15, 2020. The copyright holder for this preprint (which was not certified by peer review) is the author/funder, who has granted medRxiv a license to display the preprint in It is made available under a CC-BY-ND 4.0 International license .

92 Daily admissions to both hospital and intensive care units (ICU) were aggregated each week in 2020 and stratified into 3 age bands (0-29, 30-64 and 65+). For each week, the proportion of hospital and ICU admissions within each age group was determined. Between April and July, the proportional distribution of hospital and ICU admissions across the three categories remained fairly stable, with no evidence of rationing of service access on the basis of age.

\section{Epidemiological model}

We developed a stochastic, discrete-time, susceptible-infected-recovered epidemiological model for Manaus which we calibrated using daily time-series data from the death-certificate

100 and hospitalisation records. The model assumed an initial population size equal to that of 101 Manaus in 2019 (2,182,761), which was split into $N=36$ age/gender groups based on proportions reported in the 2010 census (i.e., 5-year age classes up to an age of 75 years, and then a pooled age class for all individuals aged 75 years and over). To allow inference on the background mortality rate in each age/gender group, the model was initiated on January 1, 2020, approximately two months prior to the introduction of COVID-19. The model was terminated after $n=202$ days on July 20, 2020, to ensure complete reporting of both death certificates and hospitalisations over the modelled period. The model detailed below was fitted within a Bayesian framework using JAGS (v. 4.3.0) software [14] and a mixture of informative and uninformative priors (for full details of the model code, including details of all prior

110 distributions, see Supplementary Appendix S1).

111 COVID-19 introduction and virus transmission. We initialised the model by allowing

112 importation of COVID-19 cases into Manaus over the week beginning March 5, 2020 (one

113 week before the first reported case), and inferred an importation model such that the number

114 of introduced cases into each group in each day of this first week arose from a Poisson process 
medRxiv preprint doi: https://doi.org/10.1101/2020.09.25.20201939; this version posted October 15, 2020. The copyright holder for this preprint (which was not certified by peer review) is the author/funder, who has granted medRxiv a license to display the preprint in It is made available under a CC-BY-ND 4.0 International license .

115 with a common mean inferred from the data. To model community transmission, we inferred

116 a reproduction number on day $t$ that was modified by an index of human mobility

$$
R_{t}=e^{\left(\log \left(R_{0}\right)+a X_{t}\right)}
$$

118 where $R_{0}$ is the basic reproduction number, $X_{t}$ is the mobility covariate and $a$ is the inferred

119 coefficient. We derived the time-series $X_{t}$ by first averaging daily data for five separate indices

120 of community mobility (available as the mobility change relative to baseline for

121 retail/recreation, grocery/pharmacy, parks, transit stations and workplaces, accessed from

122 www.google.com/covid19/mobility), and then smoothed the series with a 7-day moving-

123 average smoother. We then assumed the effective reproduction number $R_{\text {eff } f_{(i, j, t)}}$ in group $i$ due

124 to mixing with group $j$ on day $t$ is

$$
R_{e f f_{(i, j, t)}}=R_{t} Q_{i} M_{i, j} S_{i, t}
$$

126 where $Q_{i}$ is the susceptibility of group $i$ to infection, $M_{i, j}$ is the rate of mixing between the two 127 groups, and $S_{i, t}$ is the time-varying proportion of susceptible (previously uninfected) 128 individuals remaining in the focal group. Based on previous studies $[15,16]$, we used prior 129 means for the susceptibilities of $0-15,15-60$, and $60+$ year old age classes of $0.5,1.0$, and 1.3, 130 respectively.

131 Mixing between groups was governed by an age-structured mixing matrix reported previously 132 for Brazil [17], which we corrected to be symmetrical (by averaging the upper and lower 133 triangles), scaled to a mean of $1 / N$, and applied equally to both genders. The expected number 134 of new cases in each group each day was then calculated as

$$
C_{i, t}=\sum_{j=1}^{N} R_{e f f_{(i, j, t)}}\left(c_{j, 1:(t-1)} \cdot g_{(t-1): 1}\right)
$$


medRxiv preprint doi: https://doi.org/10.1101/2020.09.25.20201939; this version posted October 15, 2020. The copyright holder for this preprint (which was not certified by peer review) is the author/funder, who has granted medRxiv a license to display the preprint in It is made available under a CC-BY-ND 4.0 International license.

136 where $c_{j, 1:(t-1)}$ is the case-history vector for group $j$ and $g_{(t-1): 1}$ is the portion of the generation

137 interval distribution relevant to those cases. We used the same generation interval distribution

138 as Mellan et al. [12] which concentrated $>99 \%$ of an individual's infectivity within the first 3

139 weeks of infection (median generation interval=5 days).

140 To account for heterogeneity in transmission, we assumed the offspring distribution in group $i$

141 due to mixing with infectious individuals from group $j$ on day $t$ was governed by a negative

142 binomial distribution with mean equal to $C_{i, t}$ and variance equal to $C_{i, t}\left(1+C_{i, t} / \emptyset_{i, t}\right)$, where

$$
\emptyset_{i, t}=k C_{i, t} / R_{t}
$$

and $k$ is the overdispersion parameter, such that smaller values of $k$ represent greater transmission heterogeneity (i.e., the more transmission is due to a small number of people,

146 including by so-called "superspreaders"). Given no previous study has documented strong

147 evidence of different susceptibility between genders, we first generated the expected number

148 of new cases in each age class (regardless of gender), and then assumed gender-specific cases

149 arose from a binomial distribution with probability equal to the proportion of the total susceptible individuals for that age class attributable to each gender.

151 Background and COVID-induced mortality. We developed a model for the expected

152 number of deaths per day which was comprised of three components. First, we modelled the

153 background (pre-COVID-19) death rate $d_{i}$ estimated separately for each group. Second, 154 available data on the time from symptom onset to death for confirmed COVID-19 cases (from 155 the Manaus hospitalisation records) were used to infer a 4-parameter $\left(y_{0}, u_{\min }, u_{0}, b\right)$ mortality 156 distribution $(m)$ as a function of the time $x$ since symptom onset $(x \in\{-5, \ldots, N-5\})$ of the form

$$
m_{x+a}=\frac{y_{0} e^{u_{\min }(x+a)+\left(\left(u_{0}-u_{\min }\right) / b\right)\left(1-e^{-b(x+a)}\right)}}{\sum_{j=1}^{N} m_{j}}
$$


medRxiv preprint doi: https://doi.org/10.1101/2020.09.25.20201939; this version posted October 15, 2020. The copyright holder for this preprint (which was not certified by peer review) is the author/funder, who has granted medRxiv a license to display the preprint in It is made available under a CC-BY-ND 4.0 International license.

where $a$ is the average time from infection to symptoms, which was fixed at 5 days $[3,18,19]$.

159 Finally, we modelled the infection-fatality ratio in each group $i\left(I F R_{i}\right)$ as a log-linear function

160 of age and gender, with prior distributions on this components' parameters based on a recent

161 meta-analysis of COVID-19-induced mortality [20]. Together, these components yielded the

162 following model for the expected number of deaths

$$
D_{i, t}=d_{i}+\operatorname{IFR} R_{i} \sum_{j=1}^{N}\left(c_{j, 1:(t-1)} \cdot m_{(t-1): 1}\right)
$$

and the observed number of deaths each day was assumed to arise from a Poisson distribution with mean equal to $D_{i, t}$.

Hospitalisations due to COVID-19. Hospitalisations were modelled in a similar way to

167 COVID-induced deaths, in that available data on the time from symptom onset to hospitalisation were used to infer a 4-parameter hospitalisation distribution $(h)$ of the same functional form as that used for the mortality distribution above. We modelled the infection170 hospitalisation ratio in each group $i\left(I H R_{i}\right)$ as a logistic function of age and gender. Daily hospitalisations were assumed to arise from a Poisson distribution with mean equal to

$$
H_{i, t}=\operatorname{IHR}_{i} \sum_{j=1}^{N}\left(c_{j, 1:(t-1)} \cdot h_{(t-1): 1}\right)
$$

173 Model scenarios. Given no data were available on whether some portion of the Manaus

174 population has been self-isolating since March 2020, we initially fitted a 'baseline' model to

175 death-certificate and hospitalisation data which assumed homogeneous age-structured mixing

176 across the entire Manaus population. We compared these model outcomes to those from a second model that permitted a self-quarantined proportion $(P)$ of the population which could not be exposed to the SARS-CoV-2 virus. Communication with local experts including authors on this paper suggested that more wealthy residents of Manaus had been able to greatly reduce 
medRxiv preprint doi: https://doi.org/10.1101/2020.09.25.20201939; this version posted October 15, 2020. The copyright holder for this preprint (which was not certified by peer review) is the author/funder, who has granted medRxiv a license to display the preprint in It is made available under a CC-BY-ND 4.0 International license.

180

social interactions during the first epidemic wave and avoid exposure to the virus. We reviewed detailed socio-demographic data on Manaus [21], but were not able to source quantitative estimates of the relevant population fraction. However, we considered that this would not exceed the upper 2 income quintiles (40\%) of the population but was likely to be greater than the wealthiest $10 \%$, and accordingly, chose a non-informative uniform $(0.1,0.4)$ prior on this population fraction.

Herd-immunity threshold. To estimate the herd-immunity threshold for the baseline model scenario, we calculated the discrete-time next-generation matrix from the mixing matrix and posterior means for $R_{0}$ and age-structured susceptibilities $Q$. We then calculated the deterministic reproduction number $(R)$ as the dominant eigenvalue of this matrix, and estimated the herd-immunity threshold as $1-1 / R$. For each model, we also derived another estimate of this threshold that incorporated the inferred age/sex distribution of cases, by calculating the population-wide attack rate at which the expected number of offspring per case ( $R_{\text {eff }}$ multiplied by the normalised case-infectivity vector) fell below one.

\section{Results}

We calculated 3,457 excess deaths in Manaus, Brazil, between 19 March and 24 June 2020 (Supplementary Table 1 ) representing $0.16 \%$ of the city's population. Males 30 years and over experienced greater excess mortality than females; individuals aged 75 years or more accounted for $39 \%$ of the excess (Fig 1A). During this period, $7 \%$ of the $75+$ male population in Manaus died (Fig 1B). COVID-19 deaths were first reported from 26 March and increased weekly thereafter in keeping with improved access to diagnostics and/or increasing prevalence (Fig 2), comprising 53\% of the total excess. Other reported causes of death included respiratory diseases, unattended and unknown causes of mortality, cardiovascular, endocrine and cancer- 
medRxiv preprint doi: https://doi.org/10.1101/2020.09.25.20201939; this version posted October 15, 2020. The copyright holder for this preprint (which was not certified by peer review) is the author/funder, who has granted medRxiv a license to display the preprint in It is made available under a CC-BY-ND 4.0 International license .

203

204

205

Outcomes were similar for the second model which estimated $Q=24.5[23.0,25.1] \%$ of the

related mortality, the majority of which were compatible [22] with a clinical diagnosis of COVID-19 or are known comorbidities associated with severe outcomes (Fig 2).

Stochastic transmission models captured the observed peak in excess deaths in late April, including age and gender variation (Fig 3, Figs S1 and S2). The models also captured synchronous peaks in hospitalisations (Fig 3, Figs S3 and S4), although model fit to these data was poorer, potentially reflecting delayed recognition of COVID-19 cases and/or capacity exceedance during the epidemic peak.

Despite their different assumptions about the proportion of the Manaus population at risk, the two model scenarios yielded equivalent fits to the data (Fig 3A, B). The baseline model estimated heterogenous transmission $(\mathrm{k}=0.065$ [0.047, 0.093], mean [95 \% credible intervals]), a mean time-to-death of 13 days (Fig S5), and inferred a population-wide attack rate of 85.7 $[84.6,86.7] \%$ by 20 July. Attack rates were lowest in younger age classes (Fig 3A,i), reflecting lower susceptibility assumed for people under 15 years.

Infection fatality rate (IFR) estimates for the baseline model ranged from almost zero for both genders aged $30-35$ years, to $3.0[2.8,3.3] \%$ and $7.4[6.8,8.0] \%$ for females and males over 75 years, respectively (Fig 4). At a population level, reduced mobility resulted in variable $R_{t}$, while the expected offspring per case fell below one after April 12 (Fig S6), when the estimated attack rate was $61.8[61.1,62.6] \%$. The traditional estimate of the herd-immunity threshold based on the discrete-time next-generation matrix calculated from this model was $71.8 \%$.

Manaus population was effectively removed from the susceptible pool. Relative to the baseline model, this second model estimated the expected offspring per case fell below one after April 
medRxiv preprint doi: https://doi.org/10.1101/2020.09.25.20201939; this version posted October 15, 2020. The copyright holder for this preprint (which was not certified by peer review) is the author/funder, who has granted medRxiv a license to display the preprint in It is made available under a CC-BY-ND 4.0 International license.

22511 when the attack rate was $46.8[46.0,47.7] \%$, and reduced the final attack rate to $65.0[63.7$,

$22665.6] \%$.

\section{Discussion}

228 Early time-series modelling of the COVID-19 epidemic in Brazilian states up to 6 May 2020

229 used an unstructured model informed by state-level mobility indicators and reported deaths

230 [12]. The model inferred population attack rates ranging from $0.13 \%$ to $10.6 \%$, for Minas

231 Gerais and Amazonas, respectively, and predicted ongoing epidemic growth throughout May.

232 Other modelled $R_{0}$ estimates based on reported COVID-19 cases from Amazonas state have

233 similarly anticipated continued growth in cases through the month of June [13]. These models

234 could neither explain nor accurately forecast observations of epidemic decline in Manaus.

235 Our analysis of excess deaths and hospitalisations in Manaus identifies rapid epidemic growth

236 from late March, peaking in late April, with a return to baseline mortality in early June. These

237 age- and gender-stratified models inferred heterogeneous transmission consistent with previous

238 studies of SARS-CoV-1 [23] and SARS-CoV-2 [24]. In the baseline model, the expected

239 offspring per case fell below one at a population-wide attack rate of $61.8 \%$. This model

240 suggests the herd-immunity threshold was exceeded in Manaus, with resulting attack rates

241 inferred to be $86 \%$ by July 202020 . In contrast, the attack rate stabilised at $65 \%$ for the second

242 model which estimated the risk of infection applied to $c$. $75 \%$ of the population only. Both

243 models suggest that, primarily due to herd protection, the expected number of offspring per

244 cases fell below one in early April.

245 Although both models estimated declining SARS-CoV-2 transmission over time due to herd

246 immunity, their implications for the possibility of subsequent waves are qualitatively different.

247 Although there are currently no data to support the assertion that some fraction of the Manaus 
medRxiv preprint doi: https://doi.org/10.1101/2020.09.25.20201939; this version posted October 15, 2020. The copyright holder for this preprint (which was not certified by peer review) is the author/funder, who has granted medRxiv a license to display the preprint in It is made available under a CC-BY-ND 4.0 International license .

population self-isolated, we consider the second model is likely more realistic because: (1) the estimated infection-fatality ratios are higher than reported from high-income countries [25] which we anticipate to be plausible; and (2) a population attack rate of $65 \%$ is more consistent with recent estimates based on a Manaus blood bank serosurvey [26] which reported the largest increase in seropositivity over the month of April.

We focus on Manaus as the epicentre of the COVID-19 epidemic in Amazonas, avoiding conflation of case numbers in this dense city of more than 2 million people with slower growing rural outbreaks across the state [6]. Given known information bias associated with

256 limited early testing capacity, we used excess deaths and hospitalisations as the most objective indicators of epidemic activity presently available. Detailed cause-of-death data support the hypothesis that the majority of excess mortality over this time was COVID-19 related.

An important caveat is that estimated attack rates accumulate all infections and are agnostic to the presence or degree of symptoms. Severity of the clinical course of COVID-19 is associated with magnitude and persistence of the host immune response [27]. In consequence, our estimates of 'exposure' cannot be directly related to predicted antibody seroprevalence at the end of the first wave [28]. It is reasonably anticipated that population immunity will wane over time, requiring robust memory responses [29] to prevent reinfection or modify the clinical course [30].

Our findings support emerging evidence that population heterogeneity of SARS-CoV-2 transmission, attributable to a range of biological and sociological factors, reduces the herd immunity threshold $[24,31,32]$. Reduction of superspreading events through constraints on 270 mixing group sizes is concordant with genomic studies showing successive extinction of 271 imported strains under the influence of social and mobility restrictions [33]. 
medRxiv preprint doi: https://doi.org/10.1101/2020.09.25.20201939; this version posted October 15, 2020. The copyright holder for this preprint (which was not certified by peer review) is the author/funder, who has granted medRxiv a license to display the preprint in It is made available under a CC-BY-ND 4.0 International license.

272 While future infection clusters and outbreaks remain possible in Manaus due to unexposed

273 subgroups, population-level immunity will likely constrain widespread transmission unless

274 immunity wanes. As in other settings, underlying vulnerability of older age groups may be

275 further exacerbated over time by reduced health seeking behaviours of individuals with pre-

276 existing and new medical conditions [34]. Social measures should be informed by

277 understanding of key enablers of superspreading and amplification, awareness of at-risk

278 populations and tailored to context depending on population experience of the first wave.

279 Excess mortality data are not sufficiently timely to support real-time decision making, but in

280 areas with limited testing may be a more reliable indicator of past epidemic activity than

281 confirmed cases. To accurately support response to and assess the impact of the COVID-19

282 and other public health emergencies, improved access to diagnostics, and strengthening of

283 reporting systems are needed in low- and middle-income settings. Cross-sectional and

284 longitudinal seroprevalence studies are essential to understand markers and maintenance of

285 immunity to inform prediction of long-term epidemiologic trends and bridging to likely vaccine

286 impacts $[26,35]$.

\section{REFERENCES}

288 1. Dye C, Cheng R, Dagpunar J, Williams B. The scale and dynamics of COVID-19

$289 \quad$ epidemics across Europe. 2020.

290 2. Klein A. Australia looks to be finally beating its second wave of coronavirus https://www.newscientist.com/article/2252690-australia-looks-to-be-finally-beating-itssecond-wave-of-coronavirus2020.

293 3. Li Q, Guan X, Wu P, Wang X, Zhou L, Tong Y, et al. Early Transmission Dynamics in

294 Wuhan, China, of Novel Coronavirus-Infected Pneumonia. 2020;382(13):1199-207. doi:

295 10.1056/NEJMoa2001316. PubMed PMID: 31995857. 
medRxiv preprint doi: https://doi.org/10.1101/2020.09.25.20201939; this version posted October 15, 2020. The copyright holder for this preprint (which was not certified by peer review) is the author/funder, who has granted medRxiv a license to display the preprint in It is made available under a CC-BY-ND 4.0 International license . Contagiousness and Rapid Spread of Severe Acute Respiratory Syndrome Coronavirus 2. Emerging Infectious Disease journal. 2020;26(7):1470. doi: 10.3201/eid2607.200282.

5. Aguas R, Corder RM, King JG, Goncalves G, Ferreira MU, M. Gomes MG. Herd immunity thresholds for SARS-CoV-2 estimated from unfolding epidemics. 2020:2020.07.23.20160762. doi: 10.1101/2020.07.23.20160762 \%J medRxiv.

6. Ferrante L, Steinmetz WA, Almeida ACL, Leão J, Vassão RC, Tupinambás U, et al. Brazil's policies condemn Amazonia to a second wave of COVID-19. Nature Medicine. 2020. doi: 10.1038/s41591-020-1026-X.

7. Felix-Cardoso J, Vasconcelos H, Rodrigues P, Cruz-Correia R. Excess mortality during COVID-19 in five European countries and a critique of mortality analysis data.

8. Thompson RN, Hollingsworth TD, Isham V, Arribas-Bel D, Ashby B, Britton T, et al. Key questions for modelling COVID-19 exit strategies. Proc Biol Sci. 2020;287(1932):20201405. Epub 2020/08/13. doi: 10.1098/rspb.2020.1405. PubMed

9. Croda J, Oliveira WKd, Frutuoso RL, Mandetta LH, Baia-da-Silva DC, Brito-Sousa JD, et al. COVID-19 in Brazil: advantages of a socialized unified health system and preparation to contain cases \% J Revista da Sociedade Brasileira de Medicina Tropical.

316 10. Amazonas Health Surveillance Foundation FVS. Amazonas confirms 1st case of Covid19 and authorities guarantee that the assistance network is prepared for assistance 2020 [29 June 2020]. Available from: http://www.fvs.am.gov.br/en/noticias_view_en/3740 
medRxiv preprint doi: https://doi.org/10.1101/2020.09.25.20201939; this version posted October 15, 2020. The copyright holder for this preprint (which was not certified by peer review) is the author/funder, who has granted medRxiv a license to display the preprint in It is made available under a CC-BY-ND 4.0 International license .

11. Amazonas Health Surveillance Foundation FVS. COVID-19 Monitoring Panel. Manaus, Brazil 2020 [11 August 2020]. Available from:

\section{http://www.fvs.am.gov.br/indicadorSalaSituacao_view/60/2.}

12. Mellan TA, Hoeltgebaum HH, Mishra S. Estimating COVID-19 cases and reproduction number in Brazil. Imperial College London, 2020.

13. de Souza WM, Buss LF, Candido DDS, Carrera JP, Li S, Zarebski AE, et al. Epidemiological and clinical characteristics of the COVID-19 epidemic in Brazil. Nat Hum Behav. 2020;4(8):856-65. Epub 2020/08/02. doi: 10.1038/s41562-020-0928-4. PubMed PMID: 32737472.

14. Plummer M. JAGS: A Program for Analysis of Bayesian Graphical Models using Gibbs Sampling. 3rd International Workshop on Distributed Statistical Computing (DSC 2003); Vienna, Austria. 2003;124.

15. Zhang J, Litvinova M, Liang Y, Wang Y, Wang W, Zhao S, et al. Changes in contact patterns shape the dynamics of the COVID-19 outbreak in China. 2020;368(6498):14816. doi: 10.1126/science.abb8001\%J Science.

16. Davies NG, Klepac P, Liu Y, Prem K, Jit M, Pearson CAB, et al. Age-dependent effects in the transmission and control of COVID-19 epidemics. Nature Medicine. 2020. doi: 10.1038/s41591-020-0962-9.

17. Prem K, Cook AR, Jit M. Projecting social contact matrices in 152 countries using contact surveys and demographic data. PLOS Comput Biol. 2017;13(9):e1005697. doi: 10.1371/journal.pcbi.1005697.

18. Lauer SA, Grantz KH, Bi Q, Jones FK, Zheng Q, Meredith HR, et al. The Incubation Period of Coronavirus Disease 2019 (COVID-19) From Publicly Reported Confirmed Cases: Estimation and Application. Annals of Internal Medicine. 2020;172(9):577-82. doi: 10.7326/M20-0504. 
medRxiv preprint doi: https://doi.org/10.1101/2020.09.25.20201939; this version posted October 15, 2020. The copyright holder for this preprint (which was not certified by peer review) is the author/funder, who has granted medRxiv a license to display the preprint in It is made available under a CC-BY-ND 4.0 International license.

19. He X, Lau EHY, Wu P, Deng X, Wang J, Hao X, et al. Temporal dynamics in viral shedding and transmissibility of COVID-19. Nature Medicine. 2020;26(5):672-5. doi:

20. Levin AT, Meyerowitz-Katz G, Owusu-Boaitey N, Cochran KB, Walsh SP. Assessing the age specificity of infection fatality rates for COVID-19: systematic review, metaanalysis, and public policy implications. 2020:2020.07.23.20160895. doi:

21. United Nations Development Programme. Atlas of human development in Brazil (http://www.atlasbrasil.org.br/2013/en/perfil_m/manaus_am/, accessed 16/09/2020). 16/09/2020. Report No.

22. Excess deaths associated with COVID-19. Provisional death counts for coronavirus disease (COVID-19). National Center for Health Statistics, Centers for Disease Control and Prevention [updated August 26, 20201st September 2020]. Available from: https://www.cdc.gov/nchs/nvss/vsrr/covid19/excess_deaths.htm.

23. Lloyd-Smith JO, Schreiber SJ, Kopp PE, Getz WM. Superspreading and the effect of individual variation on disease emergence. Nature. 2005;438(7066):355-9. doi: 10.1038/nature04153.

24. Endo A, null n, Abbott S, Kucharski A, Funk S. Estimating the overdispersion in COVID-19 transmission using outbreak sizes outside China [version 3; peer review: 2 approved]. 2020;5(67). doi: 10.12688/wellcomeopenres.15842.3.

25. Levin A, Meyerowitz-Katz G, Owusu-Boaitey N, Cochran K, Walsh S. Assessing the age specificity of infection fatality rates for COVID-19: systematic review, metaanalysis, and public policy implications. 2020.

26. Buss L, Prete CA, Jr., Abrahim C, Mendrone A, Salomon T, de Almeida-Neto C, et al. COVID-19 herd immunity in the Brazilian Amazon. 2020. 
medRxiv preprint doi: https://doi.org/10.1101/2020.09.25.20201939; this version posted October 15, 2020. The copyright holder for this preprint (which was not certified by peer review) is the author/funder, who has granted medRxiv a license to display the preprint in It is made available under a CC-BY-ND 4.0 International license.

27. Long QX, Tang XJ, Shi QL, Li Q, Deng HJ, Yuan J, et al. Clinical and immunological assessment of asymptomatic SARS-CoV-2 infections. Nat Med. 2020;26(8):1200-4. Epub 2020/06/20. doi: 10.1038/s41591-020-0965-6. PubMed PMID: 32555424.

28. Hallal P, Hartwig F, Horta B, Victora G, Silveira M, Struchiner C, et al. Remarkable variability in SARS-CoV-2 antibodies across Brazilian regions: nationwide serological survey in 27 states. 2020.

29. Rodda L, Netland J, Shehata L, Pruner K, Morawski P, Thouvenel C, et al. Functional SARS-CoV-2 specific immune memory persists after mild COVID-19. 2020.

30. Ledford H. COVID-19 reinfection: three questions scientists are asking. Nature. 2020;585:168-9.

31. Britton T, Ball F, Trapman P. A mathematical model reveals the influence of population heterogeneity on herd immunity to SARS-CoV-2. 2020;369(6505):846-9. doi: 10.1126/science.abc6810\%J Science.

32. Wang Y, Teunis P. Strongly Heterogeneous Transmission of COVID-19 in Mainland China: Local and Regional Variation. 2020;7(329). doi: 10.3389/fmed.2020.00329.

33. Pybus OG, Rambaut A, du Plessis L, Zarebski AE, Kraemer MUG, Raghwani J, et al. Preliminary analysis of SARS-CoV-2 importation and establishment of UK transmission lineages. 2020.

34. Kluge HHP, Wickramasinghe K, Rippin HL, Mendes R, Peters DH, Kontsevaya A, et al. Prevention and control of non-communicable diseases in the COVID-19 response. Lancet. 2020;395(10238):1678-80. Epub 2020/05/14. doi: 10.1016/S01406736(20)31067-9. PubMed PMID: 32401713; PubMed Central PMCID: PMCPMC7211494. 
medRxiv preprint doi: https://doi.org/10.1101/2020.09.25.20201939; this version posted October 15, 2020. The copyright holder for this preprint (which was not certified by peer review) is the author/funder, who has granted medRxiv a license to display the preprint in It is made available under a CC-BY-ND 4.0 International license .

392 35. Koopmans M, Haagmans B. Assessing the extent of SARS-CoV-2 circulation through

393 serological studies. Nat Med. 2020;26(8):1171-2. Epub 2020/07/29. doi:

394 10.1038/s41591-020-1018-x. PubMed PMID: 32719488.

395

396 
medRxiv preprint doi: https://doi.org/10.1101/2020.09.25.20201939; this version posted October 15, 2020. The copyright holder for this preprint (which was not certified by peer review) is the author/funder, who has granted medRxiv a license to display the preprint in It is made available under a CC-BY-ND 4.0 International license.

397 Fig 1. Excess mortality in Manaus during the COVID-19 epidemic. (a) Total excess

398 mortality by age and gender for the period between March 19 and June 24 of 2020 . Excess

399 mortality is the 2020 weekly observed mortality less the expected mortality summed for the

400 period between March 19 and June 24 of 2020 for each subgroup. (b) Excess mortality for the

401 period between March 19 and June 24 of 2020 divided by the estimated 2019 subgroup

402 populations to obtain population proportions.

403
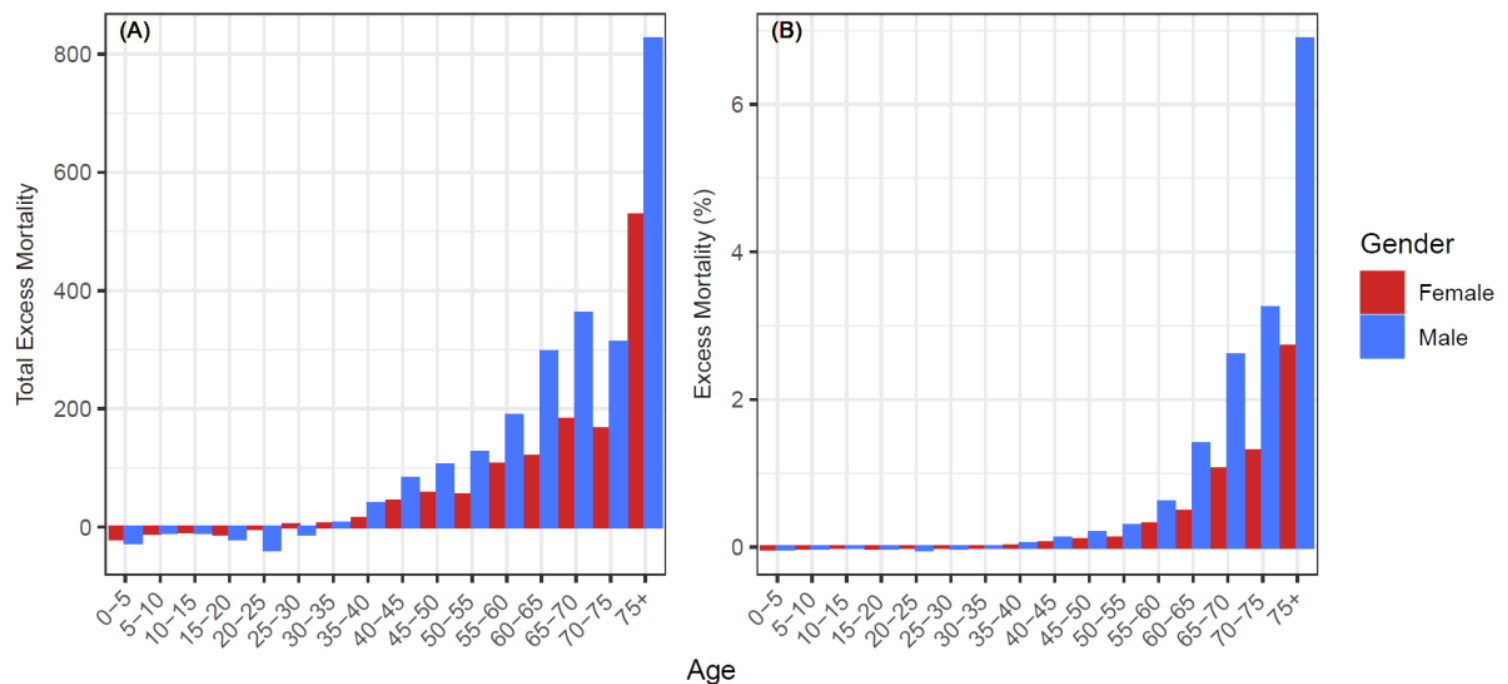

404 
medRxiv preprint doi: https://doi.org/10.1101/2020.09.25.20201939; this version posted October 15, 2020. The copyright holder for this preprint (which was not certified by peer review) is the author/funder, who has granted medRxiv a license to display the preprint in It is made available under a CC-BY-ND 4.0 International license.

407 aggregated by major ICD-10 categories of attributed causes of death.

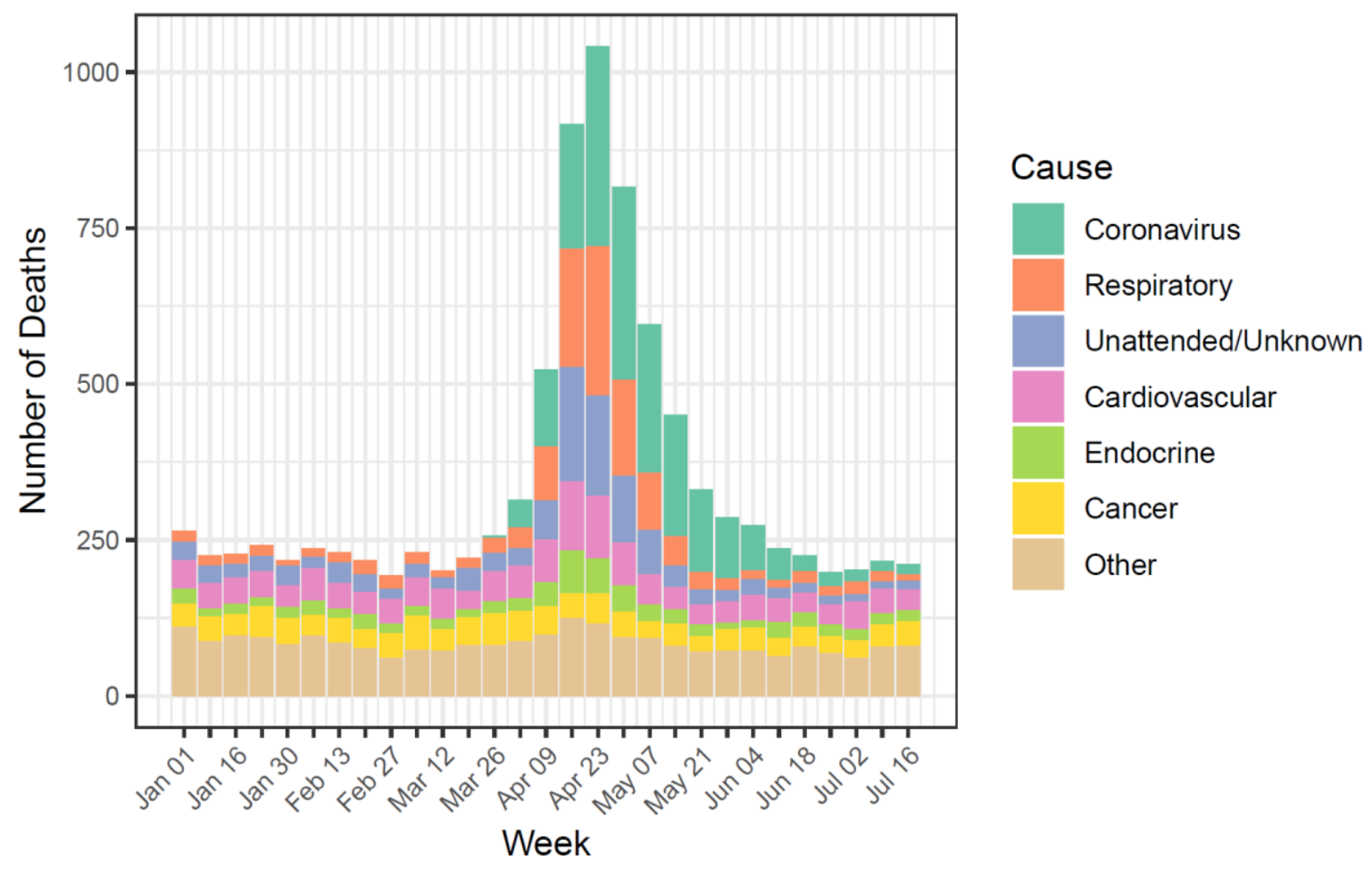


medRxiv preprint doi: https://doi.org/10.1101/2020.09.25.20201939; this version posted October 15, 2020. The copyright holder for this preprint (which was not certified by peer review) is the author/funder, who has granted medRxiv a license to display the preprint in It is made available under a CC-BY-ND 4.0 International license.

409 Fig 3. Integrated model fits by gender and model. Results are pooled at the level of three

410 aggregated age classes: (A) 0-30 years; (B) 30-60 years; and (C) 60+ years. For each age class,

411 panels (i) and (ii) show the fit of the model (lines) to the reported number of deaths and

412 hospitalisations per day (points), while panel (iii) shows inferred attack rates. Note that lines

413 showing the model fits overlap in panels (i) and (ii), and attack rates for males and females

414 overlap in panel (iii).

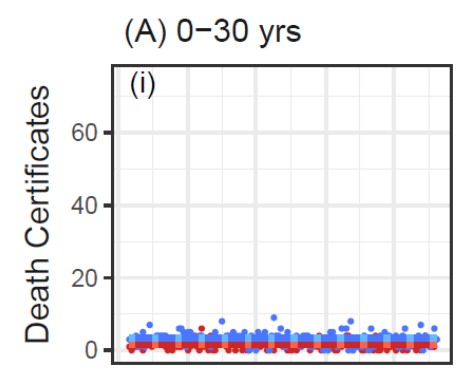

(B) $30-60$ yrs
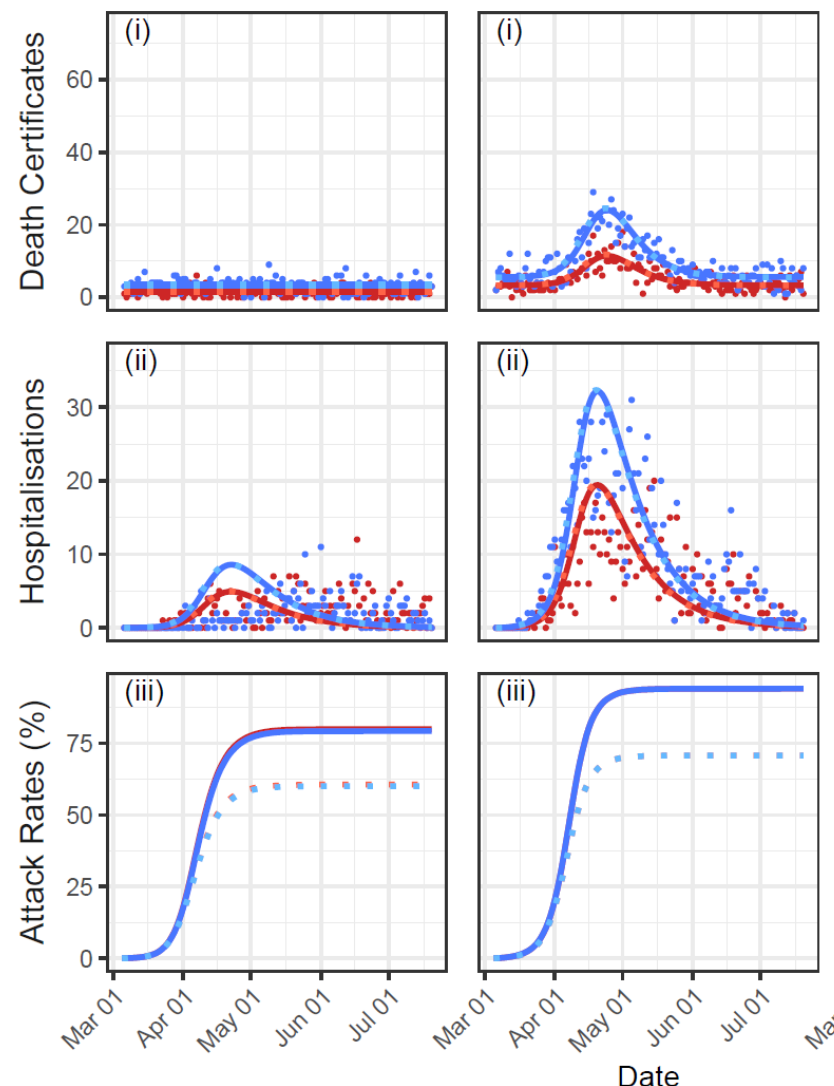

(C) $60+$ yrs
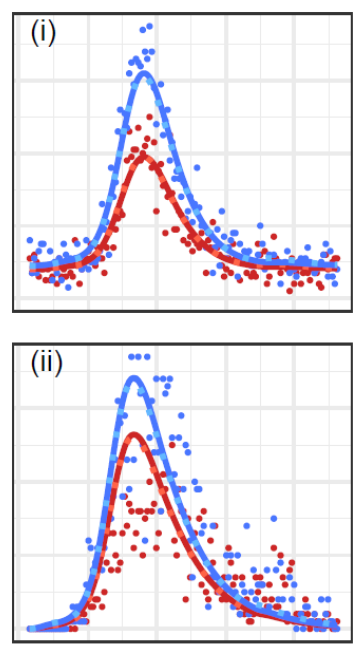

- Female (Model 1)

- Female (Model 2)

- Male (Model 1)

". Male (Model 2)

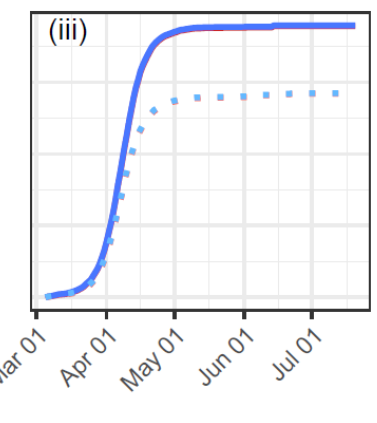


medRxiv preprint doi: https://doi.org/10.1101/2020.09.25.20201939; this version posted October 15, 2020. The copyright holder for this preprint (which was not certified by peer review) is the author/funder, who has granted medRxiv a license to display the preprint in It is made available under a CC-BY-ND 4.0 International license .

416 Fig 4. Estimated infection-fatality and infection-hospitalisation ratios. Model-based

417 estimates (mean $\pm 95 \%$ credible intervals) of age- and gender-structured (A) infection-fatality

418 ratios (IFRs) and (B) infection-hospitalisation ratios (IHRs). Note that in panel (A), IFRs were

419 fixed at zero for all age classes below 30 years.

(A) Infection-fatality ratio

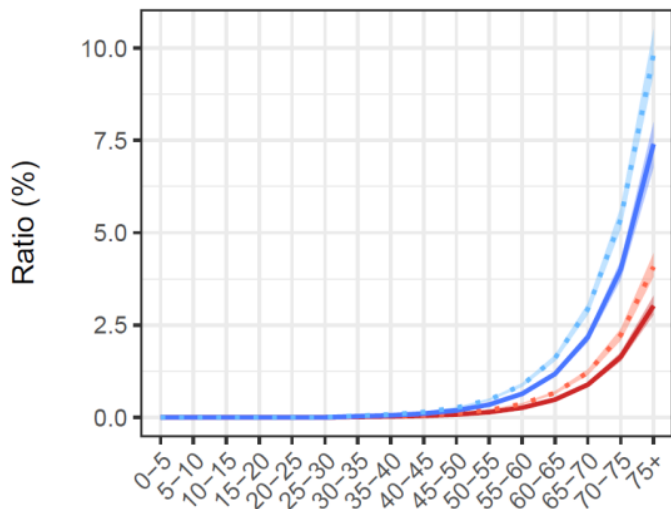

(B) Infection-hospitalisation ratio

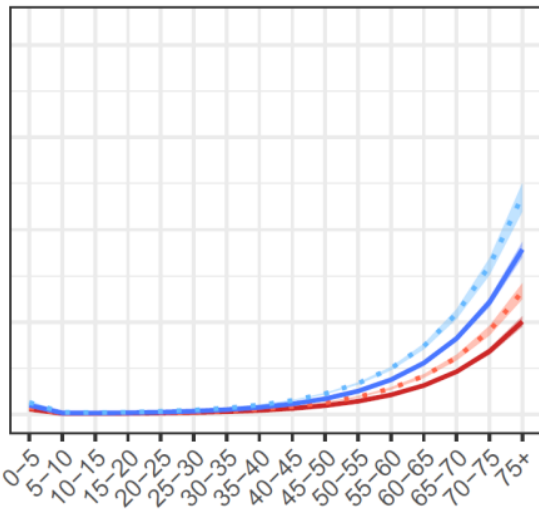

Age class
Female (Model 1)

Female (Model 2)

Male (Model 1)

Male (Model 2) 
medRxiv preprint doi: https://doi.org/10.1101/2020.09.25.20201939; this version posted October 15, 2020. The copyright holder for this preprint (which was not certified by peer review) is the author/funder, who has granted medRxiv a license to display the preprint in It is made available under a CC-BY-ND 4.0 International license .

422

423

424

425

426 Supplementary Material to:

427

428

429 Thomas A. A. Prowse, T. Purcell, Djane C. Baía-da-Silva, V. Sampaio, Wuelton M. 430 Inferred resolution through herd immunity of first COVID-19 wave in Manaus, Brazilian Amazon 
medRxiv preprint doi: https://doi.org/10.1101/2020.09.25.20201939; this version posted October 15, 2020. The copyright holder for this preprint (which was not certified by peer review) is the author/funder, who has granted medRxiv a license to display the preprint in It is made available under a CC-BY-ND 4.0 International license .

431 Table S1. Excess mortality in Manaus, Amazonas, during the COVID-19 epidemic (here

432 defined as the period between March 19 and June 24, 2020).

\begin{tabular}{|c|c|c|c|c|c|c|c|c|c|}
\hline \multirow{2}{*}{ Age } & \multicolumn{3}{|c|}{ Females } & \multicolumn{2}{c|}{ Males } & \multicolumn{2}{c|}{ Total } \\
\cline { 2 - 9 } & $\begin{array}{c}\text { Expected } \\
\text { mortality }\end{array}$ & $\begin{array}{c}\text { Observed } \\
\text { mortality }\end{array}$ & $\begin{array}{c}\text { Excess } \\
\text { mortality }\end{array}$ & $\begin{array}{c}\text { Expected } \\
\text { mortality }\end{array}$ & $\begin{array}{c}\text { Observed } \\
\text { mortality }\end{array}$ & $\begin{array}{c}\text { Excess } \\
\text { mortality }\end{array}$ & $\begin{array}{c}\text { Total } \\
\text { Excess } \\
\text { mortality }\end{array}$ & $\begin{array}{c}\text { Excess } \\
\text { mortality } \\
(\%)\end{array}$ \\
\hline $\mathbf{0 - 5}$ & 84.5 & 65 & -19.5 & 109.6 & 83 & -26.6 & $\mathbf{- 4 6 . 1}$ & $\mathbf{- 2 3 . 7}$ \\
\hline $\mathbf{5 - 1 0 .}$ & 13.2 & 3 & -10.2 & 19.3 & 10 & -9.3 & $\mathbf{- 1 9 . 5}$ & $\mathbf{- 6 0}$ \\
\hline $\mathbf{1 0 - 1 5}$ & 13.5 & 6 & -7.5 & 19.3 & 11 & -8.3 & $\mathbf{- 1 5 . 8}$ & $\mathbf{- 4 8 . 2}$ \\
\hline $\mathbf{1 5 - 2 0}$ & 26.1 & 14 & -12.1 & 64.3 & 45 & -19.3 & $\mathbf{- 3 1 . 4}$ & $\mathbf{- 3 4 . 7}$ \\
\hline $\mathbf{2 0 - 2 5}$ & 24.1 & 22 & -2.1 & 116.4 & 78 & -38.4 & $\mathbf{- 4 0 . 5}$ & $\mathbf{- 2 8 . 8}$ \\
\hline $\mathbf{2 5 - 3 0}$ & 26.7 & 30 & 3.3 & 92.2 & 81 & -11.2 & $\mathbf{- 7 . 9}$ & $\mathbf{- 6 . 6}$ \\
\hline $\mathbf{3 0 - 3 5}$ & 30 & 35 & 5 & 81.2 & 88 & 6.8 & $\mathbf{1 1 . 8}$ & $\mathbf{1 0 . 6}$ \\
\hline $\mathbf{3 5 - 4 0}$ & 38.3 & 53 & 14.7 & 79 & 118 & 39 & $\mathbf{5 3 . 7}$ & $\mathbf{4 5 . 8}$ \\
\hline $\mathbf{4 0 - 4 5}$ & 44.6 & 88 & 43.5 & 72.4 & 154 & 81.7 & $\mathbf{1 2 5 . 1}$ & $\mathbf{1 0 7}$ \\
\hline $\mathbf{4 5 - 5 0}$ & 53.3 & 110 & 56.7 & 79.8 & 184 & 104.2 & $\mathbf{1 6 0 . 9}$ & $\mathbf{1 2 0 . 8}$ \\
\hline $\mathbf{5 0 - 5 5}$ & 59.2 & 114 & 54.8 & 99 & 225 & 126 & $\mathbf{1 8 0 . 8}$ & $\mathbf{1 1 4 . 3}$ \\
\hline $\mathbf{5 5 - 6 0}$ & 73.2 & 180 & 106.8 & 121.2 & 310 & 188.8 & $\mathbf{2 9 5 . 6}$ & $\mathbf{1 5 2 . 1}$ \\
\hline $\mathbf{6 0 - 6 5}$ & 95.6 & 215 & 119.4 & 139.2 & 436 & 296.8 & $\mathbf{4 1 6 . 2}$ & $\mathbf{1 7 7 . 3}$ \\
\hline $\mathbf{6 5 - 7 0}$ & 101.6 & 283 & 181.4 & 148.6 & 510 & 361.4 & $\mathbf{5 4 2 . 8}$ & $\mathbf{2 1 6 . 9}$ \\
\hline $\mathbf{7 0 - 7 5}$ & 110.2 & 276 & 165.8 & 143.6 & 456 & 312.4 & $\mathbf{4 7 8 . 2}$ & $\mathbf{1 8 8 . 4}$ \\
\hline $\mathbf{7 5 +}$ & 468.4 & 996 & 527.6 & 382.4 & 1208 & 825.6 & $\mathbf{1 3 5 3 . 2}$ & $\mathbf{1 5 9 . 1}$ \\
\hline Total & $\mathbf{1 2 6 2 . 4}$ & $\mathbf{2 4 9 0}$ & $\mathbf{1 2 2 7 . 6}$ & $\mathbf{1 7 6 7 . 5}$ & $\mathbf{3 9 9 7}$ & $\mathbf{2 2 2 9 . 5}$ & $\mathbf{3 4 5 7 . 2}$ & $\mathbf{1 1 4 . 1}$ \\
\hline
\end{tabular}


medRxiv preprint doi: https://doi.org/10.1101/2020.09.25.20201939; this version posted October 15, 2020. The copyright holder for this preprint (which was not certified by peer review) is the author/funder, who has granted medRxiv a license to display the preprint in It is made available under a CC-BY-ND 4.0 International license .

434

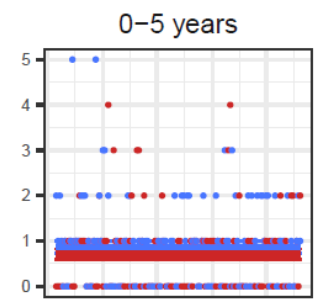

20-25 years

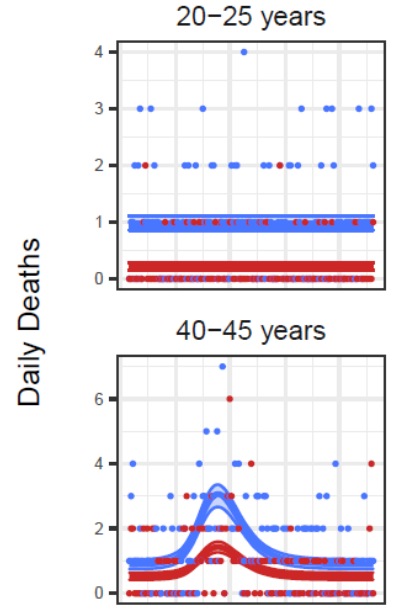

60-65 years

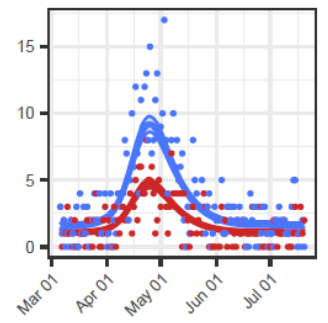

5-10 years

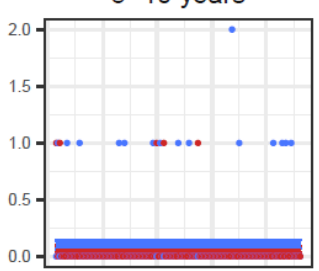

25-30 years

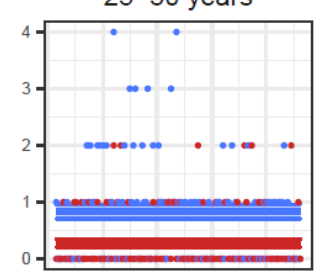

45-50 years

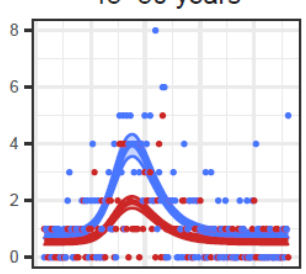

65-70 years

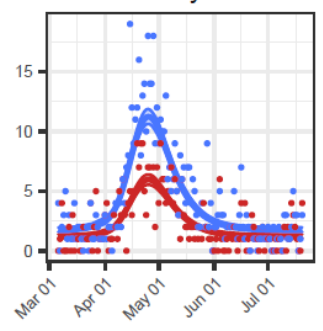

10-15 years

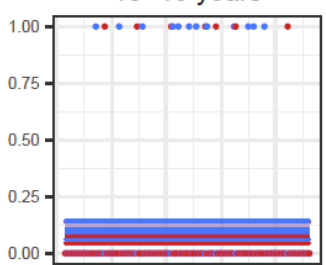

30-35 years

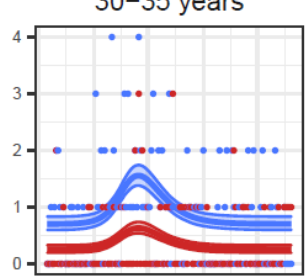

50-55 years

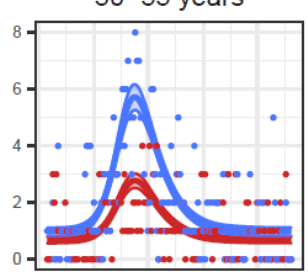

70-75 years

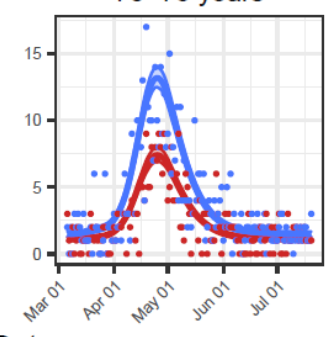

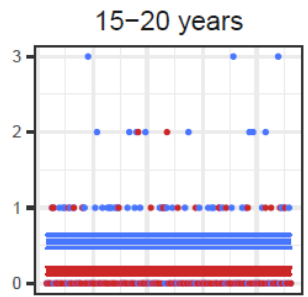

35-40 years

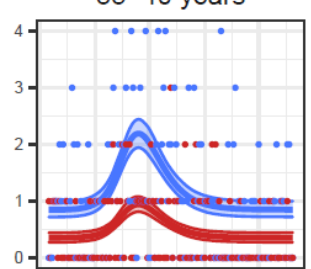

Gender

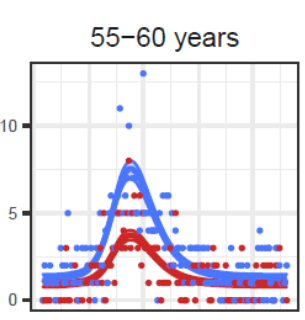

$75+$ years

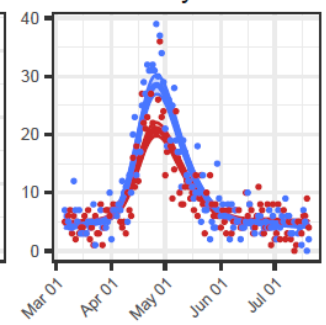

435

436

437

438

Fig S1. Baseline model fits to daily deaths data for all 32 age and gender classes. Shown are the model-inferred expected death rate from all causes (lines) $\pm 95 \%$ credible intervals (ribbons), and the mortality data used for model fitting (points). 
medRxiv preprint doi: https://doi.org/10.1101/2020.09.25.20201939; this version posted October 15, 2020. The copyright holder for this preprint (which was not certified by peer review) is the author/funder, who has granted medRxiv a license to display the preprint in It is made available under a CC-BY-ND 4.0 International license .
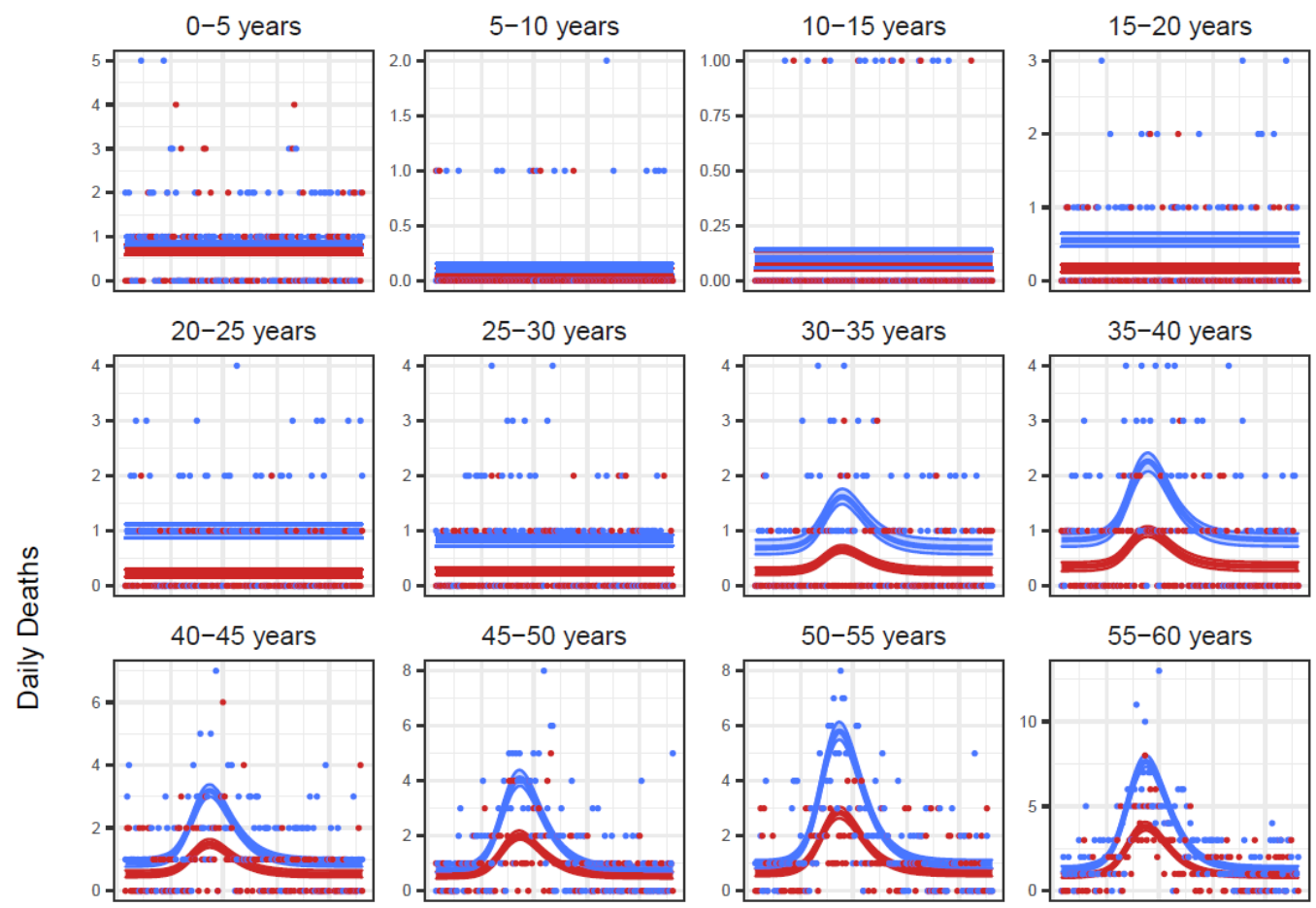

Gender
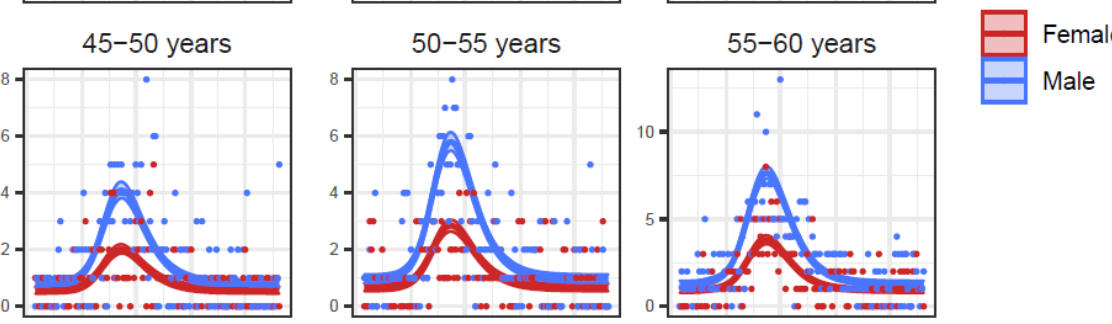

439
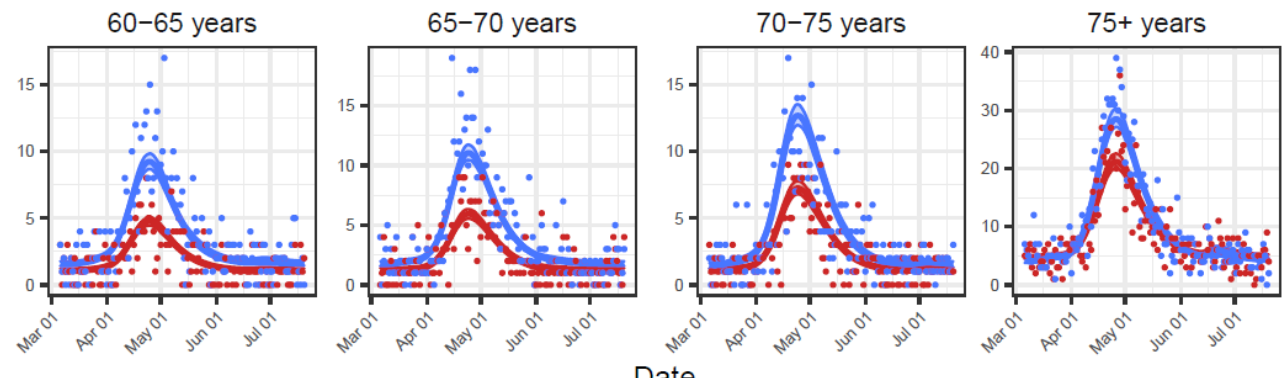

440 Fig S2. The fit of Model 2 to daily deaths data for all 32 age and gender classes. Shown are

441 the model-inferred expected death rate from all causes (lines) $\pm 95 \%$ credible intervals

442 (ribbons), and the mortality data used for model fitting (points). 
medRxiv preprint doi: https://doi.org/10.1101/2020.09.25.20201939; this version posted October 15, 2020. The copyright holder for this preprint (which was not certified by peer review) is the author/funder, who has granted medRxiv a license to display the preprint in It is made available under a CC-BY-ND 4.0 International license .

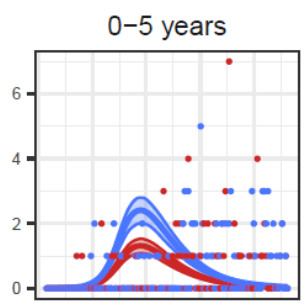

20-25 years
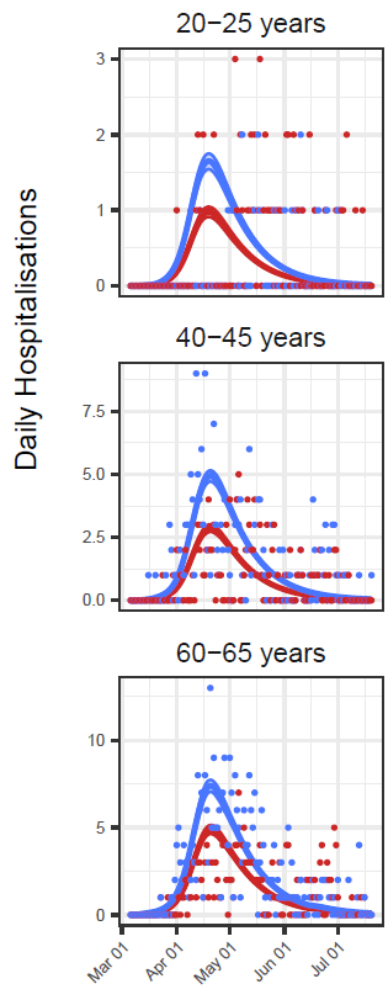

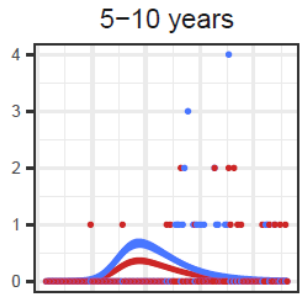

25-30 years

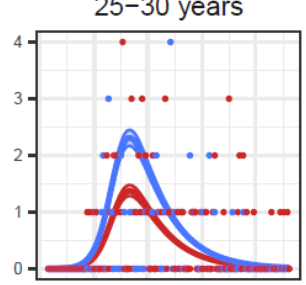

45-50 years

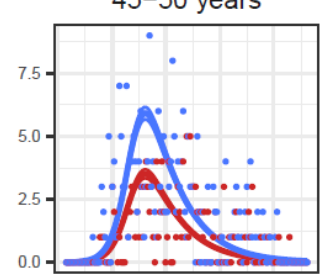

65-70 years

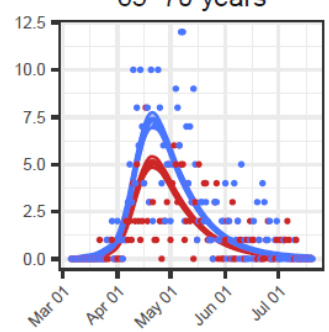

10-15 years

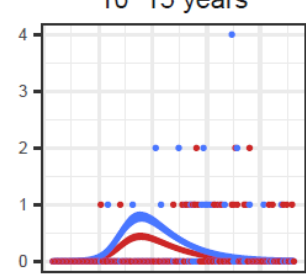

30-35 years

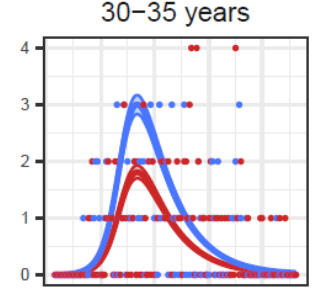

50-55 years

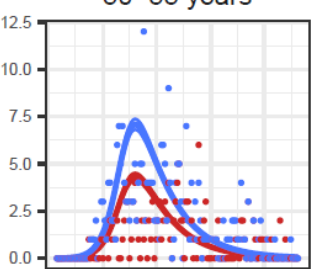

70-75 years

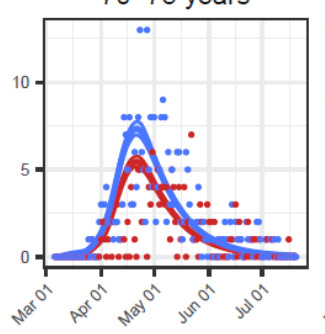

Date

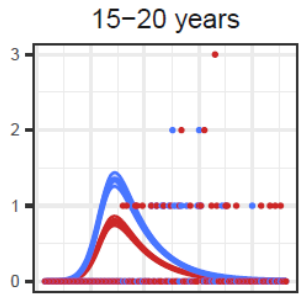

$35-40$ years

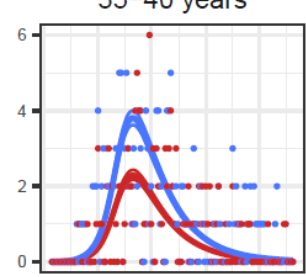

55-60 years

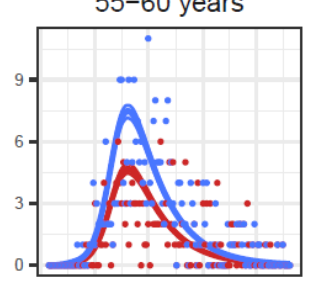

$75+$ years

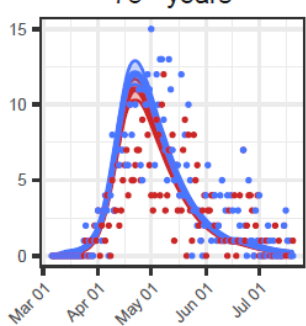

Gender

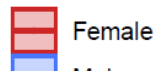

Male

444 Fig S3. Baseline model fits to hospitalisations data for all 32 age and gender classes. Shown

445 are the model-inferred expected hospitalisation rate (lines) $\pm 95 \%$ credible intervals (ribbons)

446 and the hospitalisations data used for model fitting (points). 
medRxiv preprint doi: https://doi.org/10.1101/2020.09.25.20201939; this version posted October 15, 2020. The copyright holder for this preprint (which was not certified by peer review) is the author/funder, who has granted medRxiv a license to display the preprint in It is made available under a CC-BY-ND 4.0 International license .

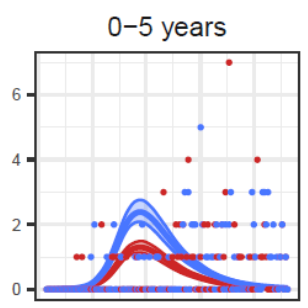

20-25 years
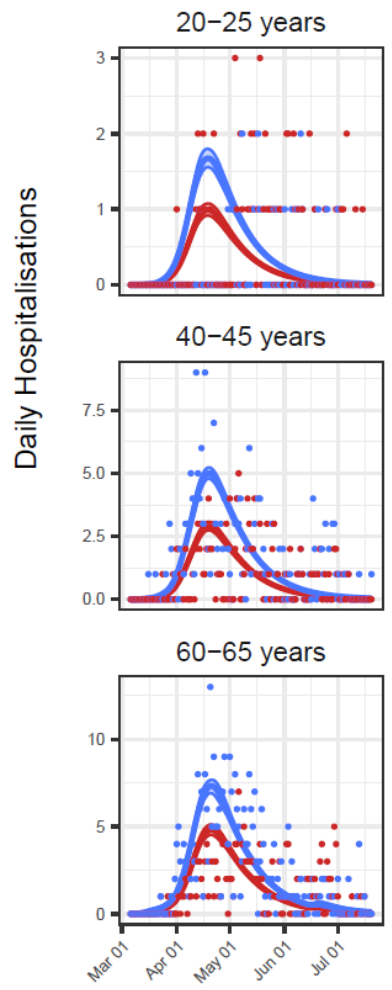

5-10 years

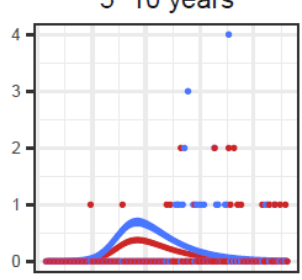

$25-30$ years

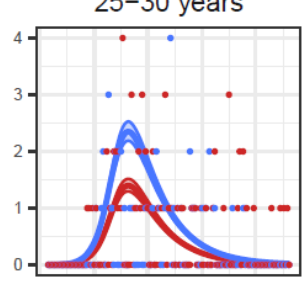

45-50 years

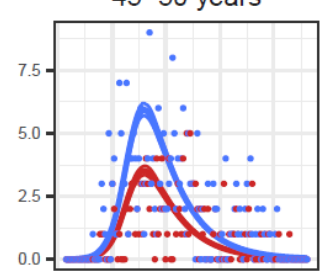

65-70 years

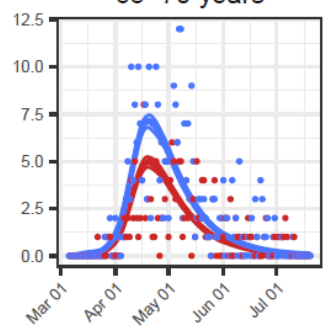

10-15 years

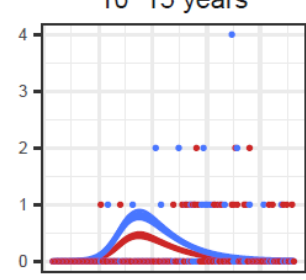

30-35 years

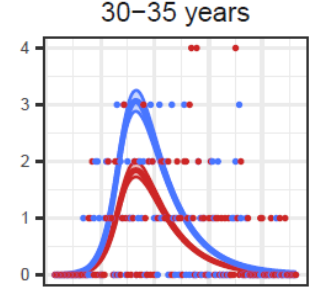

50-55 years

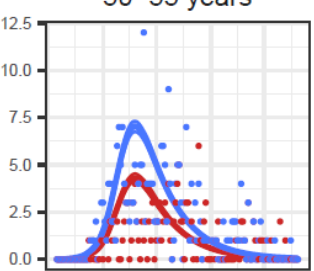

70-75 years

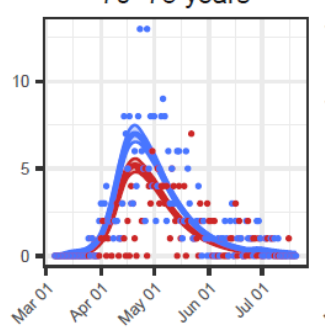

$15-20$ years

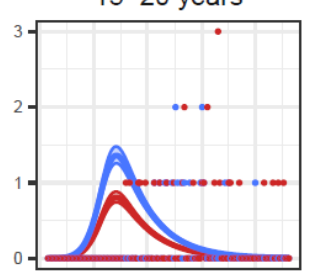

35-40 years

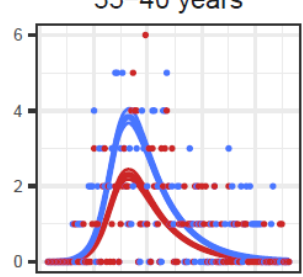

55-60 years

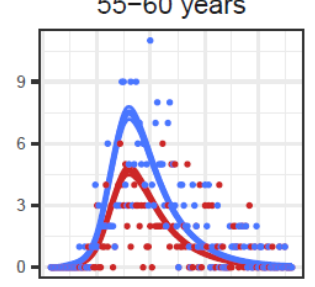

$75+$ years

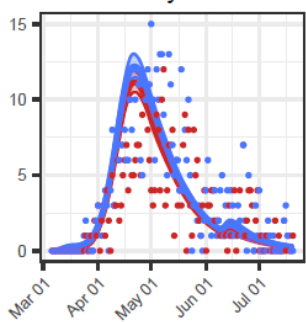

Gender

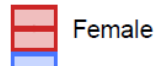

Male

Date

448 Fig S4. The fit of Model 2 to hospitalisations data for all 32 age and gender classes. Shown are the model-inferred expected hospitalisation rate (lines) $\pm 95 \%$ credible intervals (ribbons) and the hospitalisations data used for model fitting (points). 
medRxiv preprint doi: https://doi.org/10.1101/2020.09.25.20201939; this version posted October 15, 2020. The copyright holder for this preprint (which was not certified by peer review) is the author/funder, who has granted medRxiv a license to display the preprint in It is made available under a CC-BY-ND 4.0 International license .

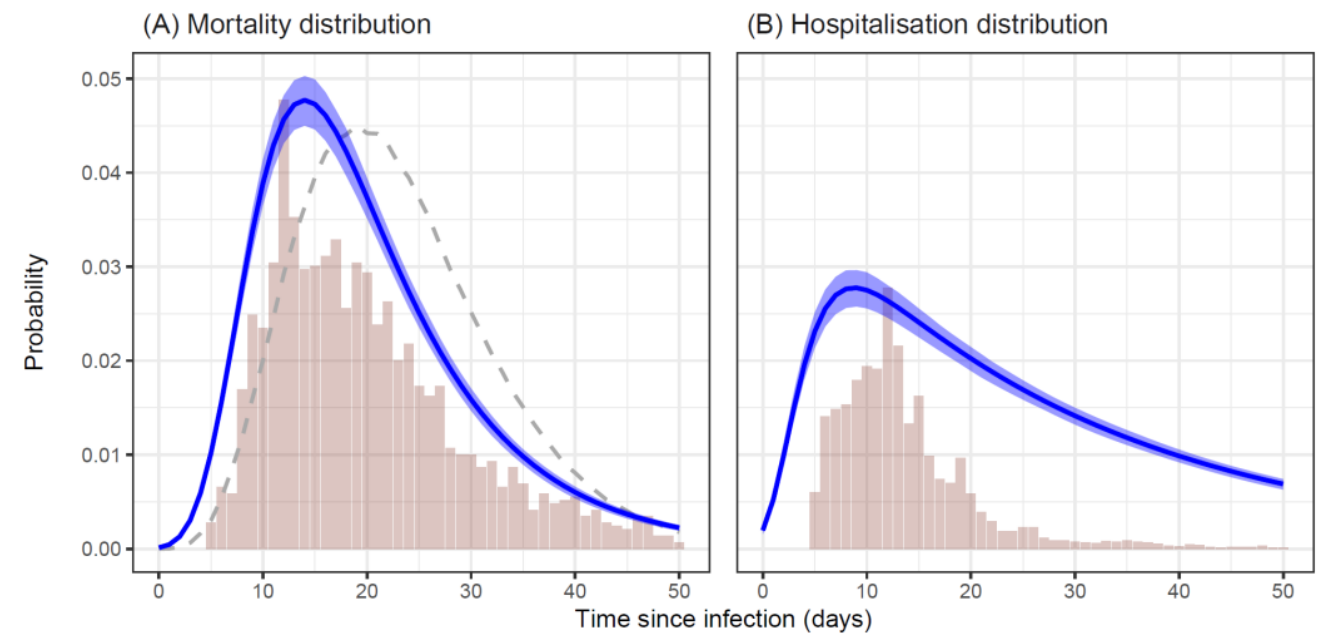

452 Fig S5. Estimates from the baseline model (mean $\pm 95 \%$ credible intervals) of the shape of 453 the (A) mortality distribution and (B) hospitalisation distribution, as a function of time since 454 infection. Vertical bars indicate empirical frequencies derived from hospitalisation records 455 for Manaus. In (A), the dashed line indicates the mortality distribution used by a previous 456 COVID-19 modelling study for the State of Amazonas, Brazil [12]. 
(A) $R_{t}$

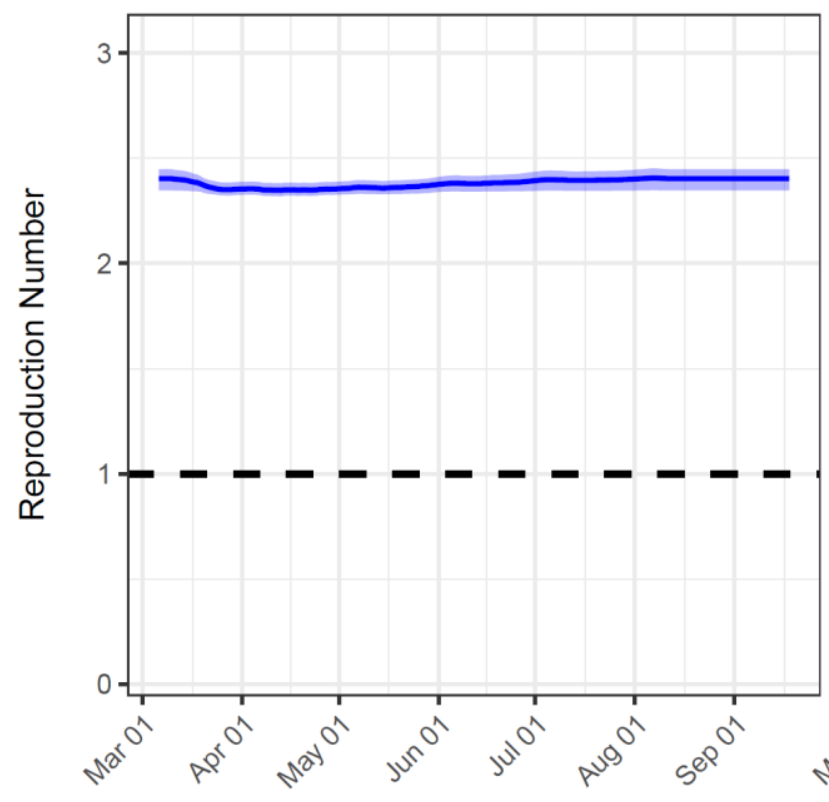

(B) $R_{\text {eff }}$

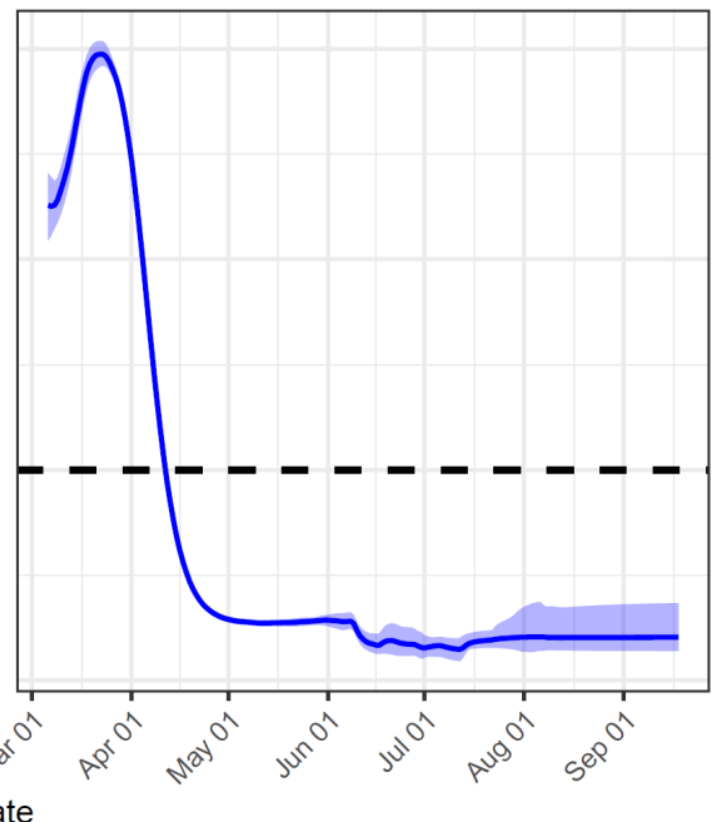

458 Fig S6. Estimates from the baseline model (mean $\pm 95 \%$ credible intervals) of: (A) the

459 impact of personal mobility on the time-varying reproduction number $\left(R_{t}\right)$; and (B) the

460 population-level effective reproduction number $\left(R_{e f f}\right)$ over time, which here is calculated as

461 the sum of the products of all $R_{e f f_{(i, j, t)}}$ and the normalised case-infectivity vectors at each

462 time $t$. In the latter, $R_{\text {eff }}$ rises initially as the case distribution converges on the stable

463 distribution, and $R_{\text {eff }}<1$ indicates the switch to negative epidemic growth due to the

464 development of herd immunity. 